\title{
Strong summer monsoon during the cool MIS-13
}

\author{
Q. Z. Yin ${ }^{1,2}$ and Z. T. Guo ${ }^{1}$ \\ ${ }^{1}$ Institute of Geology and Geophysics, Chinese Academy of Sciences, P.O. Box 9825, Beijing 100029, China \\ ${ }^{2}$ Institut d'Astronomie et de Géophysique G. Lemaître, Université catholique de Louvain, Chemin du Cyclotron 2, 1348 \\ Louvain-La-Neuve, Belgium \\ Received: 1 October 2007 - Published in Clim. Past Discuss.: 11 October 2007 \\ Revised: 18 January 2008 - Accepted: 20 February 2008 - Published: 28 February 2008
}

\begin{abstract}
The $\delta^{18} \mathrm{O}$ record in deep-sea sediments show a significant reduced amplitude of the ice volume variations before Marine Isotope Stage 11, about $400 \mathrm{ka}$ ago, with less warm interglacials and less cold glacials. The deuterium temperature and the greenhouse gases records in the Antarctic ice cores show the same feature. As the reduction in the amplitude of climate and greenhouse gases concentration variations before $400 \mathrm{kaBP}$ is present in both deep-sea and ice cores, it is tempting to conclude that this is a worldwide phenomenon. This is not necessarily true, at least as far as some of the records, in particular of China and Europe, are concerned. The loess in northern China, the sedimentary core in the eastern Tibetan Plateau and the palaeosols in southern China all record an unusually warm and wet climate during Marine Isotope Stage 13, indicating an extremely strong East Asian summer monsoon. The pollen record from Europe shows that the climatic conditions during the interglacials previous to Marine Isotope Stage 11 are at least as warm as the younger interglacials. During Marine Isotope Stage 13, unusually strong African and Indian monsoon are recorded in the sediments of the equatorial Indian Ocean and of the Mediterranean Sea. Other extreme climate events are also recorded in sediment cores of the equatorial Atlantic, the Pacific, the subtropical South Atlantic Ocean and in the Lake Baikal of Siberia.
\end{abstract}

Correspondence to: Q. Z. Yin

(yin@astr.ucl.ac.be)
The need to better understand the global climatic system leads inevitably to the close inspection of paleoclimatic archives to provide a long-term perspective from which any future change may be more effectively assessed. Such climatic variations of the past are perhaps best illustrated by the oxygen isotopic composition of calcium carbonate in marine organism tests which leads to the definition of Marine Isotopic Stages (MIS). These fluctuations are explained in terms of changing global ice volumes. They are characterized by warmer periods (interglacials which are assigned odd numbers) and colder periods (glacials which are assigned even numbers) defining the glacial-interglacial cycles of the last few millions years.

Based on such records, two major transitions have been identified for the Quaternary climate. The mid-Pleistocene revolution (MPR) is characterized by an increase in mean global ice volume, and a change in the dominant period from 41 to $100 \mathrm{ka}$ (Imbrie et al., 1993; Raymo et al., 1997). Its timing is often considered to be at about $900 \mathrm{ka} \mathrm{BP}$. A second distinct climate change, the mid-Brunhes event (MBE, Jansen et al., 1986), roughly corresponds to the transition between MIS-12 and MIS-11 about $430 \mathrm{ka}$ ago. The MBE is characterized by a further increase of ice-volume variations with four large-amplitude 100-ka glacial-interglacial cycles from then to present day (Fig. 1). The intermediate period between MPR and MBE is characterized by a less-clear pattern, with significantly weaker amplitude of ice-volume variations than after MBE. The deuterium measurements in the EPICA dome $\mathrm{C}$ ice core (EPICA, 2004; Jouzel et al., 2007) show also the same characteristics with less cold glacial maxima and very significantly less warm interglacials during the period before MIS-11 than after (Fig. 1). Not only the deuterium temperature record shows a reduced amplitude but also the $\mathrm{CO}_{2}$ and $\mathrm{CH}_{4}$ variations (Siegenthaler et al., 2005; Spahni et al., 2005). Explaining the reduction in the amplitude of these variations before MIS-11 is certainly one of the exciting challenge for the paleoclimate community over the next years. 


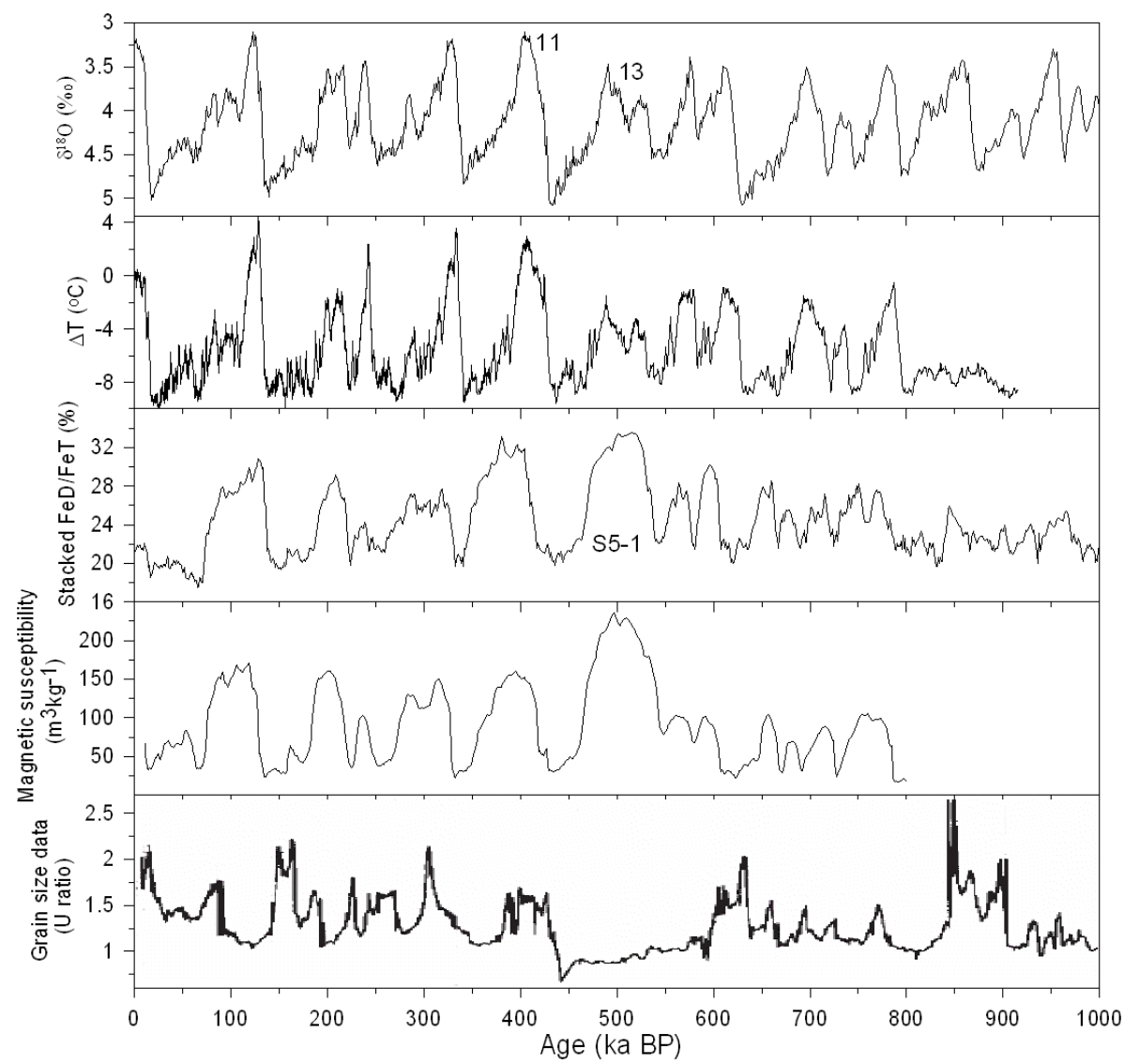

Fig. 1. Comparison of the loess proxy data with marine benthic $\delta^{18} \mathrm{O}$ and Antarctic deuterium temperature records. From the top to the bottom panel, the curves are the benthic $\delta^{18} \mathrm{O}$ stack (Lisiecki and Raymo, 2005), EPICA Dome C ice core temperature anomaly (Jouzel et al., 2007), the stacked FeD/FeT ratio (Guo et al., 2000), magnetic susceptibility (Kukla, 1987) and grain size data (Vandenberghe et al., 1997) of the loess.

As this phenomenon is present in both deep-sea and ice cores, it is tempting to conclude that this is a worldwide phenomenon with signs of "cool" interglacials before MIS-11 over the whole Earth. This is not necessarily true, at least as far as the records from China and some other records from Europe in particular are concerned.

Chinese loess, which covers an area of about half a million square kilometers (Fig. 2) with a thickness of 150$300 \mathrm{~m}$, provides one of the most complete and sensitive terrestrial records for the past climatic changes (Liu, 1985). The loess-soil sequences are constituted by loess layers alternating with paleosols layers. Loess layers are interpreted as having been deposited during glacials, and soils developed during interglacials. The alternations between soil and loess layers are commonly interpreted as an indication of the waxing and waning of the East Asian monsoon circulation, with the soil-forming periods corresponding to a strengthened summer monsoon and loess deposits to a strengthened winter monsoon (An et al., 1990). Soil layers are designated as "S", loess layers are designated as "L", and they are numbered sequentially downward. Based upon independently dated stacks obtained from the Chinese loess sections on the one hand and the deep-sea cores on the other hand (Kukla, 1987), S0 soil unit can be correlated to MIS-1, S1 to MIS-5, S4 to MIS-11 which is the longest interglacial over the last $450 \mathrm{ka}$ (Berger and Loutre, 2003), and S5-1 to MIS-13 (Liu, 1985). Paleoclimate reconstructions based on morphological comparison of paleosols and loess units with present day soils (Liu, 1985) suggest that mean annual temperature during the formation of the $\mathrm{S} 1, \mathrm{~S} 4$ and $\mathrm{S} 5$ pedocomplexes did not differ significantly (it is about $13^{\circ} \mathrm{C}$ ), but that precipitation ranged from $680 \mathrm{~mm}$ for $\mathrm{S} 1,650 \mathrm{~mm}$ for $\mathrm{S} 4$ and $800 \mathrm{~mm}$ for S5. Based on paleopedological and geochemical data of three loess sections, Guo et al. (1998) estimate an approximate increase of at least $4-6^{\circ} \mathrm{C}$ for the annual mean temperature and an increase of $200-300 \mathrm{~mm}$ for the annual rainfall for the S5-1 soil in comparison with the modern conditions. The climofunction of Lü et al (Lü et al., 1994) suggests a maximum rainfall increase of $325 \mathrm{~mm}$ for S5-1 in the central Loess Plateau region compared to the present-day. Similar results were obtained from carbon and oxygen isotope composition (e.g. Han et al., 1997, An et al., 2005), from 
pedological characteristics (e.g. An and Wei, 1980; Vidic et al., 2003), from geochemical properties (e.g. Chen et al., 1999; Guo et al., 2000), from pollen assemblages (Wu et al., 2004), from magnetic susceptibility (e.g. Kukla, 1987; Hao and Guo, 2005) and grain size data (e.g. Vandenberghe et al., 1997). These results show that S5-1 soil has undergone the most intense pedogenesis (Fig. 1) and represents the greatest humidity of the past $2.5 \mathrm{Ma}$ and a climatic condition at least as warm as those during the interglacials younger than the MBE.

At the same time, in the eastern Tibetan Plateau (Fig. 2), the high sedimentary carbonate content within a lacustrine and fluvial sediment core from the Zoige Basin implies an unusually warm and wet climate during MIS-13 (Chen et al., 1999). The pollen and charcoal data from this core also distinguish MIS-13 from the other interglacials over the last $800 \mathrm{ka}$ and indicate the appearance of forest or mixed forestgrassland in the catchment basin during MIS-13.

This extreme climate is not only recorded in the loess of northern China and the sediment core in the eastern Tibetan Plateau, but is also recorded in the paleosol of southern China, which is widely distributed in the areas south of the Yangtze River. The prominent characteristic of that soil, called Vermiculated Red Soil (VRS), is a mixture of red and white veins. Based on micromorphological, chemical and mineralogical methods, Yin and Guo (2006) investigated VRS from two sections (Fig. 2) and concluded that the red and white veins were formed from a previously homogeneous matrix, with much more abundant iron oxides in the red veins than in the white veins. This iron-depletion from the white veins differs from the ordinary oxidation-reduction by a near complete removal of iron and by their wide geographic extents in southern China, a difference which indicates abundant rainfall throughout the year without significant desiccations.

On the other hand, paleomagnetic stratigraphy and luminescence measurement (Qiao et al., 2003) allow to conclude that VRS formation dates back between 850 and $360 \mathrm{ka} \mathrm{BP}$. As VRS is the most developed soil since $850 \mathrm{ka} \mathrm{BP}$ in southern China, one might attempt to correlate it with the strongest developed soil, S5-1, in northern China. As this last soil represents a period of greatest humidity, it can be concluded that the white veins within VRS correspond mainly to S5-1 which itself correlates to MIS-13, so providing an age of roughly $500 \mathrm{ka} \mathrm{BP}$.

Because the investigated regions are under the influence of the East Asian Summer Monsoon (EASM), the extremely abundant rainfall in China as early as $500 \mathrm{kaBP}$ ago indicate primarily an extremely strong EASM. This extremely strong MIS-13 EASM coincides with other exceptional events recorded in the terrestrial and marine records in the world. The Polish pollen record of the Ferdynandowian interglacial which is correlated with the S5 in China (Vandenberghe, 2000), shows climatic conditions during the interglacials previous to the MBE are at least as warm as the

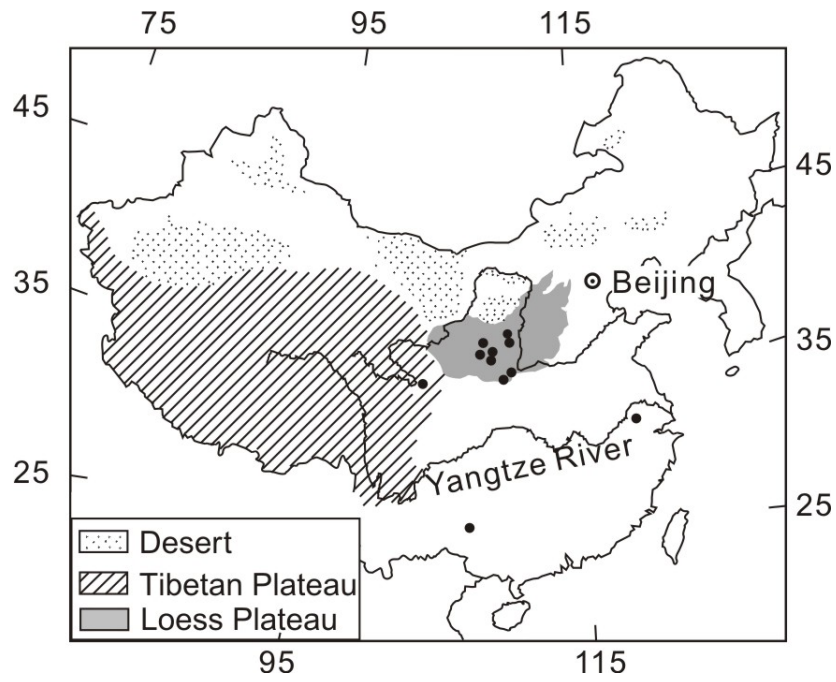

Fig. 2. The map indicates the main sites (black dots, referred in this paper) in China where extremely strong East Asian summer monsoon during MIS-13 is recorded. These are listed below from north to south: Jiaodao $\left(35.9^{\circ} \mathrm{N}, 109.4^{\circ} \mathrm{E}\right)$, Luochuan $\left(35.75^{\circ} \mathrm{N}\right.$, $\left.109.42^{\circ} \mathrm{E}\right), \quad$ Xifeng $\left(35.63^{\circ} \mathrm{N}, \quad 107.42^{\circ} \mathrm{E}\right), \quad$ Changwu $\left(35.2^{\circ} \mathrm{N}\right.$, 107. $\left.7^{\circ} \mathrm{E}\right), \quad$ Chaona $\left(35.12^{\circ} \mathrm{N}, \quad 107.2^{\circ} \mathrm{E}\right), \quad \operatorname{Lingtai}\left(35.07^{\circ} \mathrm{N}\right.$, $\left.107.65^{\circ} \mathrm{E}\right), \quad$ Weinan $\left(34.33^{\circ} \mathrm{N}, \quad 109.48^{\circ} \mathrm{E}\right), \quad \operatorname{Lantian}\left(34.12^{\circ} \mathrm{N}\right.$, $\left.109.17^{\circ} \mathrm{E}\right), \mathrm{RH} \operatorname{core}\left(33.9^{\circ} \mathrm{N}, 102.53^{\circ} \mathrm{E}\right)$, Xuancheng $\left(30.9^{\circ} \mathrm{N}\right.$, $\left.118.85^{\circ} \mathrm{E}\right)$ and Bose $\left(23.77^{\circ} \mathrm{N}, 106.7^{\circ} \mathrm{E}\right)$.

younger interglacials (Rzechowski, 1996). The same conclusion is made for the youngest Cromerian interglacials and equivalents (Zagwijn, 1996) which are time equivalent roughly with S5 and next older Chinese soils (interglacials). Prokopenko et al. (2002) note that the region around Lake Baikal (Siberia) remained forested through MIS-11 to MIS15 , which suggests that the climate there was nor arid neither particularly cold. The severely reduced eolian mass accumulation rates at 540 ka recorded in KK75-02 core from Pacific (Janecek and Rea, 1984) indicate an increasing humidity at the beginning of MIS-13 in Central Asia. A thick sapropel deposited in the deep eastern Mediterranean Sea following high floods of the Nile river and dated at 528-525 ka ago by astronomical tuning using insolation variations described by a monsoon index indicates unusually heavy monsoon rainfall over Africa (Rossignol-Strick et al., 1998). At the same time, at $525 \mathrm{ka} \mathrm{BP}$, in the equatorial Indian Ocean there was an extreme event of low surface-water salinity caused by heavy monsoonal fluvial discharge to the ocean (Bassinot et al., 1994). The Mediterranean sapropel is also synchronous with an unusual mid-Pleistocene climate excursion (Gingele and Schmieder, 2001), indicated by unique carbonate-rich diatom ooze layers deposited under the low productivity regime of the subtropical gyre in the South Atlantic. The fraction of goethite in total iron oxides, a precipitation proxy in the terrigenous sediments from Ceara Rise in the western tropical Atlantic Ocean, has a maximum peak during MIS-13, 
indicating a maximum precipitation over the lowland Amazon Basin (Harris and Mix, 1999). Finally, the stable benthic foraminiferal $\delta^{13} \mathrm{C}$ from different oceans indicates that the $\delta^{13} \mathrm{C}$ maximum events appear during MIS-13 (e.g. Raymo et al., 1997; Wang et al., 2004).

Facing this seeming paradox of extreme monsoon climates during a cool interglacial, it is useful to recall that this peak in monsoon activity is also associated with a maximum in $\delta^{13} \mathrm{C}$ recorded in deep-sea cores from different oceans. Three important factors may affect the deep ocean $\delta^{13} \mathrm{C}$ values. Firstly, an increase in continental biomass may result in a rise of the average $\delta^{13} \mathrm{C}$ of the oceans (Raymo et al., 1990). Secondly, the organic versus inorganic ratio in oceanic carbon deposition influences the $\delta^{13} \mathrm{C}$ value, and $\delta^{13} \mathrm{C}$ maximum occurs when the ratio is unusually high (Wang et al., 2004). Thirdly, the North Atlantic deep-water (NADW), which is formed with an initial high $\delta^{13} \mathrm{C}$ value flows southwards to the Southern Ocean and then to the Pacific. Such a circulation may therefore affect the deep ocean $\delta^{13} \mathrm{C}$ values on a worldwide scale (Raymo et al., 1990, 1997). Consequently, the coupling between the summer monsoon proxy and the world ocean $\delta^{13} \mathrm{C}$ records may be explained in three possible ways: (1) Continental land biomass significantly increased during the periods when the summer monsoon was particularly strengthened; (2) Enhanced weathering and runoff caused by strengthened summer monsoon can supply a high silica flux to the oceans, which in turn leads to high organic/inorganic ratios and finally leads to a high $\delta^{13} \mathrm{C}$ value (Wang et al., 2004); and/or (3) the strengthened summer monsoon is coupled with a stronger rate of formation of NADW. Although data do not show exceptional strengthening of NADW at MIS-13 (e.g. Fig. 5d in Raymo et al., 1990), we can not definitely reject this suggestion trying to explain the cool MIS-13 recorded in EPICA ice core through the so-called "see-saw" argument (Stocker and Johnsen, 2003): stronger NADW would indeed bring more heat from the equator and the Southern Hemisphere to the Northern Hemisphere, leading to a cooler Southern Hemisphere and a warmer Northern Hemisphere, which would possibly lead to stronger monsoon.

Is such an intense EASM related to the long term variations of the energy that the Earth is receiving from the Sun? Prell and Kutzbach (1987) showed that paleoclimatic records adjacent to India and Africa over the last 150000 years displayed four monsoon maxima which occurred during interglacial conditions and coincided with summer solstice at perihelion and with maxima of Northern Hemisphere summer radiation. From general circulation model experiments, they concluded that under interglacial conditions, increased Northern Hemisphere incoming solar radiation (or insolation) produces a strong monsoon because of a larger landocean pressure gradient, stronger winds and greater precipitation. In addition for MIS-1 and 5e, such insolation maxima also occur around the peaks of MIS-11, 13 and 15. For example, $60^{\circ} \mathrm{N}$ June insolation is $46,66,41,50$ and $58 \mathrm{Wm}^{-2}$ above the present-day value of $476 \mathrm{Wm}^{-2}$ (Berger, 1978), respectively $11,128,410,505$ and $600 \mathrm{ka}$ ago. However, as MIS-13 receives less insolation, is more glaciated but has a monsoon stronger than MIS-5e, it is not obvious that a high insolation can alone explain the strong monsoon there. There are indeed two competing factors coming into play, insolation and ice sheets. On one hand, mollusk assemblages in the Chinese Loess Plateau reflect a strengthened summer monsoon during the glacials MIS-10 and 12 (Wu et al., 2007), and also during the younger glacial MIS-6.5 (Rousseau and $\mathrm{Wu}, 1999)$. The latter has been confirmed by some modeling experiments which show that the glacial conditions do not prevent high insolation to generate an increased monsoon activity during MIS-6.5 (175 ka BP) (Masson et al., 2000). On another hand, observations and modeling studies have shown that a large Eurasian snow cover would have, for present day, a negative impact on monsoon strength (Barnett et al., 1989; Vernekar et al., 1995), and an increased high latitudes glacial ice cover (11 and $18 \mathrm{ka} \mathrm{BP}$ ) reduces summer monsoon over South Asia (Prell and Kutzbach, 1987; DeMenocal and Rind, 1993). This duality makes the problem definitely more complex, but does not mean that we can exclude the possibility that ice sheets might partly solve this seeming paradox of having a strong monsoon during a cool interglacial. Another possibility might be related to Asian orography (mainly the Tibetan Plateau) which seems to play an important role on Asian monsoon (Kutzbach et al., 1989; DeMenocal and Rind, 1993).

This apparently global cool (more ice) MIS-13 interglacial accompanied by a very strong EASM in China and other extreme events over the world was quite unexpected. More data must be found at the regional scale to see whether or not such a much less warm interglacial and extreme warm and wet events are also observed locally. Moreover, climate model experiments must be made to test whether such strong monsoon in East Asia can exist during a cool interglacial and if yes, why.

Acknowledgements. Yin Q. Z. thanks EGU for the Keith Runcorn Travel Award for Non-Europeans which allowed her to deliver an oral presentation at the General Assembly 2006 and the Belgium FNRS (Fonds National belge de la Recherche Scientifique) for a "Bourse de séjour scientifique" as a visiting researcher at Université catholique de Louvain in Louvain-la-Neuve. A. Berger is thanked for his valuable discussions and comments. D. D. Rousseau, J. Vandenberghe and another anonymous referee are thanked for their constructive comments.

Edited by: D.-D. Rousseau 


\section{References}

An, Z. S. and Wei, L. Y.: The fifth layer paleosol in the Lishi loess and their paleoclimatic significance, Acta Pedologica Sinica, 17, 1-10, 1980.

An, Z. S., Liu, T. S., Lu, Y. C., Porter, S. C., Kukla, G., Wu, X. H., and Hua, Y.: The long-term paleomonsoon variation recorded by the loess-paleosol sequence in central China, Quat. Int., 7, 9196, 1990.

An, Z. S., Huang, Y. S., Liu, W. G., Guo, Z. T., Clemens, S., Li, L., Prell, W., Ning, Y. F., Cai, Y. J., Zhou, W. J., Lin, B. H., Zhang, Q. L., Cao, Y. N., Qiang, X. K., Chang, H., and Wu, Z. $\mathrm{K}$.: Multiple expansions of $\mathrm{C} 4$ plant biomass in East Asia since 7 Ma coupled with strengthened monsoon circulation, Geology, 33(9), 705-708, 2005.

Barnett, T. P., Dümenil, L., Schlese, U., Roeckner, E., and Latif, M.: The effect of Eurasian snow cover on Regional and global climate variations, J. Atmos. Sci., 46(6), 661-685, 1989.

Bassinot, F. C., L. D. Labeyrie, E. Vincent, X. Quidelleur, N. J. Shackleton, and Y. Lancelot: The astronomical theory of climate and the age of the Brunhes-Matuyama magnetic reversal, Earth Planet. Sci. Lett., 126, 91-108, 1994.

Berger, A.: Long-term variations of daily insolation and Quaternary Climatic Changes, J. Atmos. Sci., 35(12), 2362-2367, 1978.

Berger, A. and Loutre M.F.: Climate 400,000 years ago, a key to the future? in: Earth's Climate and Orbital Eccentricity: The Marine Isotope Stage 11 Question, edited by: Droxler, A., Poore, R., and Burckle, L., Geophysical Monograph Series, 137, 17-26, 2003.

Chen, F. H., Bloemendal, J., Zhang, P. Z., and Liu, G. X.: An 800 ky proxy record of climate from lake sediments of the Zoige Basin, eastern Tibetan Plateau, Palaeogeogr. Palaeocl., 151, 307-320, 1999.

Chen, J., An, Z. S., Wang, Y. J., Ji, J. F., Chen, Y., and Lu, H. Y.: Distribution of $\mathrm{Rb}$ and $\mathrm{Sr}$ in the Luochuan Loess-paleosol sequence of China during the last 800 ka-implications for paleomonsoon variations, Sci. China, 42(3), 225-232, 1999.

DeMenocal, P. B. and Rind, D.: Sensitivity of Asian and African climate to variations in seasonal insolation, glacial ice cover, sea surface temperature, and Asian orography, J. Geophys. Res., 98(4), 7265-7287, 1993.

EPICA community members: Eight glacial cycles from an Antarctic ice core, Nature, 429, 623-628, 2004.

Gingele, F. X. and Schmieder, F.: Anomalous South Atlantic lithologies confirm global scale of unusual mid-Pleistocene climate excursion, Earth Planet. Sci. Lett., 186, 93-101, 2001.

Guo, Z. T., Liu, T. S., Fedoroff, N., Wei, L. Y., Ding, Z. L., Wu, N. Q., Lü, H. Y., Jiang, W. Y., and An, Z. S.: Climate extremes in Loess of China coupled with the strength of Deep-Water Formation in the North Atlantic, Global Planet. Change, 18, 113-128, 1998.

Guo, Z. T., Biscaye, P., Wei, L. Y., Chen, X. F., Peng, S. Z., and Liu, T. S.: Summer monsoon variations over the last $1.2 \mathrm{Ma}$ from the weathering of loess-soil sequences in China, Geophys. Res. Lett., 27, 1751-1754, 2000.

Han, J. M., Keppens, E., Liu, T. S., Paepe, R., and Jiang, W. Y.: Stable Isotope Composition of the Carbonate Concretion in Loess and Climate Change, Quatern. Int., 37, 37-43, 1997.

Hao, Q. Z. and Guo, Z. T.: Spatial variations of magnetic susceptibility of Chinese loess for the last 600 kyr: Implications for monsoon evolution, J. Geophys. Res., 110, B12101,
doi:10.1029/2005JB003765, 2005.

Harris, S. E. and Mix, A. C.: Pleistocene precipitation Balance in the Amazon Basin recorded in deep sea sediments, Quaternary Res., 51, 14-26, 1999.

Imbrie, J., Berger, A., Boyle, E. A., Clemens, S. C., Duffy, A., Howard, W. R., Kukla, G., Kutzbach, J., Martinson, D. G., McIntyre, A., Mix, A. C., Molfino, B., Morley, J. J., Peterson, L. C., Pisias, N. G., Prell, W. L., Raymo, M. E., Shackleton, N. J., and Toggweiler, J. R.: On the structure and origin of major glaciation cycles. 2. The 100,000-year cycle, Paleoceanography, 8(6), 699-735, 1993.

Janecek, T. R. and Rea, D. K.: Pleistocene fluctuations in Northern Hemisphere tradewinds and westerlies, in: Milankovitch and Climate, edited by: Berger, A., Imbrie, J., Hays, J., Kukla, G., and Saltzman, B., D. Reidel, Norwell, Mass, 331-347, 1984.

Jansen, J. H. F., Kuijpers, A., and Troelstra, S. R.: A Mid-Brunhes climatic event: Longterm changes in global atmosphere and ocean circulation, Science, 232, 619-622, 1986.

Jouzel, J., Masson-Delmotte, V., Cattani, O., Dreyfus, G., Falourd, S., Hoffmann, G., Minster, B., Nouet, J., Barnola, J. M., Chappellaz, J., Fischer, H., Gallet, J. C., Johnsen, S., Leuenberger, M., Loulergue, L., Luethi, D., Oerter, H., Parrenin, F., Raisbeck, G., Raynaud, D., Schilt, A., Schwander, J., Selmo, E., Souchez, R., Spahni, R., Stauffer, B., Steffensen, J. P., Stenni, B., Stocker, T. F., Tison, J. L., Werner, M., and Wolff, E. W.: Orbital and Millennial Antarctic Climate Variability over the Past 800,000 Years, Science, 317, 793-796, 2007.

Kukla, G.: Loess stratigraphy in central China, Quaternary Sci. Rev., 6, 191-219, 1987.

Kutzbach, J. E., Guetter, P. J., Ruddiman, W. F., and Prell, W. L.: Sensitivity of climate to late Cenozoic uplift in southern Asia and the American West, J. Geophys. Res., 94, 18 393-18 407, 1989.

Lisiecki, L. E. and Raymo, M. E.: A Pliocene-Pleistocene stack of 57 globally distributed benthic delta 180 records, Paleoceanography, 20(1), PA1003, doi:10.1029/2004PA001071, 2005.

Liu, T. S.: Loess and the Environment, China Ocean Press, Beijing, 1985.

Lü, H. Y., Han, J. M., Wu, N. Q., and Guo, Z. T.: Magnetic susceptibility of the modern soils in China and paleoclimatic significance, Sci. China, 24, 1290-1297, 1994.

Masson, V., Braconnot, P., Jouzel, J., de Noblet, N., Cheddadi, R., and Marchal, O.: Simulation of intense monsoons under glacial conditions, Geophys. Res. Lett., 27, 1747-1750, 2000.

Prell, W. L. and Kutzbach, J. E.: Monsoon variability over the past 150000 years, J. Geophys. Res., 92, 8411-8425, 1987.

Prokopenko, A. A., Williams, D. F., Kuzmin, M. L., Karabanov, E. B., Khursevich, G., and Peck, J. A.: Muted climate variations in continental Siberia during the mid-Pleistocene epoch, Nature, 418, 65-68, 2002.

Qiao, Y. S., Guo, Z. T., Hao, Q. Z., Wu, W. X., Jiang, W. Y., Yuan, B. Y., Zhang, Z. S., Wei, J. J., and Zhao, H.: Loess-soil sequences in Southern Anhui Province: Magnetostratigraphy and paleoclimatic significance, Chinese Sci. Bull., 48(13), 1465-1469, 2003.

Raymo, M. E., Oppo, D. W., and Curry, W.: The mid-Pleistocene climate transition: a deep sea carbon isotopic perspective, Paleoceanography, 12, 546-559, 1997.

Raymon, M. E., Ruddiman, W. F., Shackleton, N. J., and Oppo, D. W.: Evolution of Atlantic-Pacific d13C gradients over the last 2.5 My, Earth Planet. Sci. Lett. 97, 353-368, 1990. 
Rossignol-Strick, M., Paterne, M., Bassinot, F. C., Emeis, K.-C., and De Lange, G. J.: An unusual mid-Pleistocene monsoon period over Africa and Asia, Nature, 392, 269-272, 1998.

Rousseau, D. D. and Wu, N.: Mollusk record of monsoon variability during the L2-S2 Cycle in the Luochuan loess sequence, China, Quaternary Res., 52, 286-292, 1999.

Rzechowski, J.: The Ferdynandowian Interglacial and its stratigraphical position in the Middle Pleistocene of Europe, in: The early Middle Pleistocene in Europe, edited by: Turner, C., Balkema, Rotterdam, 279-293, 1996.

Siegenthaler, U., Stocker, T. F., Monnin, E., L“uthi, D., Schwander, J., Stauffer, B., Raynaud, D., Barnola, J.-M., Ficher, H., MassonDelmott, V. and Jouzel, J.: Stable carbon cycle-climate relationship during the late Pleistocene, Science, 310, 1313-1317, 2005.

Spahni, R., Chappellaz, J., Stocker, T. F., Loulergue, L., Hausammann, G., Kawamura, K., Fluckiger, J., Schwander, J., Raynaud, D., Masson-Delmotte, V., and Jouzel, J.: Atmospheric Methane and Nitrous Oxide of the Late Pleistocene from Antarctic Ice Cores, Science, 310, 1317-1321, 2005.

Stocker, T. F. and Johnsen, S. J.: A minimum model for the bipolar seesaw, Paleoceanography, 18, 1087, doi:10.1029/2003PA000920, 2003.

Vandenberghe, J., An, Z., Nugteren, G., Lu, H., and Van Huissteden, J.: New absolute time scale for the Quaternary climate in the Chinese loess region by grain-size analysis, Geology, 25(1), 35-38, 1997.

Vandenberghe, J.: A global perspective of the European chronostratigraphy for the past $650 \mathrm{ka}$, Quaternary Sci. Rev., 19, 17011707, 2000.
Vernekar, A. D., Zhou, J., and Shukla, J.: The effect of Eurasian snow cover on the Indian monsoon, J. Climate, 8, 248-266, 1995.

Vidic, N. J., Verosub, K. L., and Singer, M. J.: The Chinese Loess Perspective on Marine Isotope Stage 11 as an Extreme Interglacial, in: Earth's Climate and Orbital Eccentricity: The Marine Isotope Stage 11 Question, edited by: Droxler, A., Poore, R., and Burckle, L., Geophysical Monograph Series, 137, 231-240, 2003.

Wang, P., Tian, J., Cheng, X., Liu, C., and Xu, J.: Major Pleistocene stages in a carbon perspective: The South China Sea record and its global comparison, Paleoceanography, 19, PA4005, doi:10.1029/2003PA000991, 2004.

Wu, F. L., Fang, X. M., Ma, Y. Z., An, Z. S., and Li, J. J.: A 1.5 Ma sporopollen record of paleoecologic environment evolution in the central Chinese Loess Plateau, Chinese Sci. Bull., 49, 295-302, 2004.

Wu, N. Q., Chen, X. Y., Rousseau, D. D., Li, F. J., Pei, Y. P., and Wu, B.: Climatic conditions recorded by terrestrial mollusk assemblages in the Chinese Loess Plateau during marine Oxygen Isotope Stages 12-10, Quaternary Sci. Rev., 26, 1884-1896, 2007.

Yin, Q. Z. and Guo, Z. T.: Mid-Pleistocene vermiculated red soils in southern China as an indication of unusually strengthened East Asian monsoon, Chinese Sci. Bull., 51(2), 213-220, 2006.

Zagwijn, W.: The Cromerian Complex Stage of the Netherlands and correlation with other areas in Europe, in: The early Middle Pleistocene in Europe, edited by: Turner, C., Balkema, Rotterdam, 145-172, 1996. 